\title{
The American Dream: Its Echoes and Possibilities in Literary Discourse
}

\author{
Dr Kalu, Kalu Obasi ${ }^{1}$ \\ ${ }^{1}$ Veritas University Abuja, The Catholic University of Nigeria, Federal Capital Territory of Nigeria \\ Correspondence: Dr Kalu, Kalu Obasi, Veritas University Abuja, The Catholic University of Nigeria, Federal Capital \\ Territory of Nigeria
}

Received: December 6, 2017

Accepted: January 2, 2018

Online Published: January 12, 2018

doi:10.5430/elr.v7n1p1

URL: https://doi.org/10.5430/elr.v7n1p1

\begin{abstract}
The American Dream stems from the inaugural speech of President Franklin Roosevelt's "Four Freedoms"(1941). The Four Freedoms envisaged an American society where the freedom of worship, freedom of speech, freedom of movement and the rights to life are enshrined, guaranteed, and accommodated. America has been clouded with numerous yearnings from all angles - politics, academic, economic, among other social upheavals for the enthronement of the Four Freedoms. Literary scholars have diminutively expressed the horrors of African Americans in various forms and shades, and have hopefully waited for the day it will be implemented. This paper attempts to relay the horrors, echoes, and possibilities of the American Dream as expressed by literary scholars, and the mass media. It also attempts to unveil the measures the African Americans have tried to live within the face of the horrors that have attained their existence among the White Americans. The possibilities of their struggles to live above subjugations, oppressions, the Jim Crow Laws, and racial discrimination that have rocked the American society for decades are also within the wavelength of this work.
\end{abstract}

Keywords: The American Dream, Echoes, Possibilities, Literary discourse

\section{Introduction}

The American Dream stems from President Franklin D. Roosevelt's (1941) inaugural speech delivered at the Congress in 1941, when America was at the brink of war threat, causing him to declare "at no previous time has American security been as seriously threatened from without as it is today"(Stuart Murray and James McCabe,(1993:3). Roosevelt had said earlier that; "United State must become the arsenal of democracy" (qtd in Murray and McCabe, 1993:5), to supply Britain in her fight against the axis powers of Germany and Italy. This broadcast had given hope to many people in the European countries occupied by the Nazis and gave inspiration to the Americans (Murray and McCabe1993:6). His address had been directed toward the statement that; "Enduring peace cannot be bought at the expense of other people's freedom" (Murray and McCabe, 1993:5). Roosevelt declared on January 6,1941 that:

In the future days, which we seek to make secure, we look forward to a world founded upon four essential human freedoms. The first is freedom of speech and expression - everywhere in the world... freedom of worship of God, everywhere in the world, freedom from want - which translated into world terms means economic understanding which will secure to every nation a healthy peacetime life for its inhabitants everywhere in the world, and freedom from fear - which translated into world terms means a world- wide reduction of armament... anywhere in the world (Murray and McCabe, 1993:6).

The American dream is the realization of the four essential freedoms as enunciated by President Roosevelt. The American dream is important to the America society, the American citizens, particularly, the African Americans who came into America in a state of humiliation. The American history has been a long tale from the circumstance of slavery, humiliation and violence. These are issues which have affected the lives of African American citizens. According to Samuel Yette,(1971), "The conquest of the American land by the Europeans was accompanied by tremendous amount of violence, massive destruction of pre-existing civilizations, plunder and exploitation bordering on genocide, competition, and war between European powers"(16). The exploration of America brought about a process of cultural interactions between African nations and other European nations. The effect of these interactions is more positive than negative to the Europeans. Yette (1971) posits that, "the African Americans in the New 
World - America were quite useful in the economic development of America yet were regarded as Obsolete human Scrap heap"(17) by the Europeans. According to Uya (2005), "The American society is a land of cultural pluralism which was woven together from the various African nations as a result of slave trade, is a land where the African nations relied upon and hoped for as a means of survival"(168). Many Africans, mostly freed men accompanied the Spanish in their expeditions in America. Uya (2005) maintains that Men like Juan Garrido, Juan Cirtes, Nuflo de Olano and Juan Vliente, played crucial roles in the success of the expeditions often credited to the Splanish.

Chinweizu et al, (1981) state that:

For nearly six centuries now Western Europe and its Diaspora have been disturbing the peace of the world. Enlightened, through their renaissance, by the learning of the ancient Mediterranean, armed with the gun, the making of whose powder they had learned from Chinese fire crackers; equipping their ships with latent sails, ... fortified in aggressive spirit by arrogant, messianic Christianity of both the popish and protestant varieties; and motivated by the lure of enriching plunder,... have sallied forth ...to explore, assault, loot, occupy, rule and exploit the rest of the world. And even... their expansionist assault upon the rest of us has not abated (3).

The history of Africans in America is a tale of oppression, violence, suppression, and exploitation culminating into racism. Another issue of great importance among the Africans in the development of American is in the area of culture. Being native of various Africa decent, they brought together their different cultural values to the useful colouration of the America nation with rich cultural values. This statement is corroborated by Uya (2005) in his work, African Diaspora and the Black Experience in the New World Slavery as he state that; “...African slaves in the New World created a universe in which the African cultural impulse was unmistakable" (205). Africans, despite their condition of entry and stay in America under violence, humiliation and threats were able to survive, grow, and transmit their African cultures to their descendants.

Apart from cultural dimensions, the Africans were useful in their contributions to religious life and institutions, music, songs, and folklore which they transmitted in their new home, America. This found expressions in the Negro spirituals, the blues, Jazz, and souls of the United State of America, the calypso and reggae of the Carribeans and other neighbouring countries. These music types are impressive comment on the human conditions of the Blacks. Jazz for example has been described by one of its greatest protagonist, Dizzy Gillespie, as as Uya (2005) notes that it is "a creation in America not through any great educational force, but the soul of the people who were brought here under protest '"( 207).The Negro spirituals independently capture the full range of human emotions, loneliness, challenges of commitment, patience, tragedies, triumphs, failures, successes, trials, frustrations and fate, (Uya, 2005:205). Thus the Africans being transported to a strange land, and described as disease infested, primitive, and dangerous, have a long trail of agony behind them. The Africans survived all these conditions with courage and triumphed to the point of self identity and recognition.

This portrayal is indeed, a manifestation that the African American writer is fully aware of the dictates of language and its essence for modification, correction, protest against hypocrisy and for the creation of awareness for both the Blacks and Whites in America. Change is the only permanent thing in nature and language and esthetics in arts are products of change. This work is not intended to compromise racism or to propagate it, it is within the scholarly practice of criticism and evaluation of various trends which shape violence and black literary art in American. The need to subscribe to peace and tranquility inform the necessity for this paper. The African American writers leave an indelible landmark in literature in their attempt to leave a lasting print in the literary domain. They explore the state of violence in the society they are found. Violence is a universal phenomenon that social scientists explore to portray the causes of conflicts in their various works and these conflicts are amiably resolved. Violence is expressed when there is a conflict between a person and the existing system where he belongs. Anifowose point out that:

Violence has been used by groups seeking power, by groups in the process of losing power, and by groups holding power. Violence has been preserved in the defense of order by the privileged, in the name of justice by the oppressed and in fear of displacement by the threatened (1).

Similarly in literary circle, violence occurs when writers attempt to use their literary works, ethos, or canon to express the need for change in the society they find themselves. Again, violence is carried out in art when writers use their literary works in the contemplation to make bare various levels of economic stagnation, environmental assaults, and issues of identity among other social and political ills. The idea of Jonathan V. Crowe et al (1999) in Acts of Memory: Cultural Recall in the Present is called into use in the expression of this paper. They posit that: 
Literature is an important carrier and constructor of cultural phenomena that intersects with history. It is strategic because it helps humans make sense of their world, narratives (whether literary, visual or oral form),(105).

African American writers have used their works within the praxis of narratology to reconstruct the historical temperament of the American society with the view for the concern for human development across political and social narratives. They tend to use their literary works to ascertain a change in the cruel system by revising memory and history. The revision of history and memory is of great concern to literary scholars and writers. This informs the statement of Pierre Nora in her work Les Lieux de Memoire (1984) that:

Memory and history are fundamental literary elements in the understanding of the ethos of the people, it opens the dialectic of remembering and forgetting unconscious of its successive deformations in art. It also helps in the architectonic reconstruction of the narrative drive in fiction (35).

Bureaux, D.(1981), Moors, A.(1995), and Fabian J.(1983,1996) in Ogunyemi Babatunde (2006), agree that history and memory give a clear narratological image to fiction. They enable the critic to understand the social, economic and political background in the analysis of societal trends which constitute the integral nature of art. African American writers are products of history and memory because their works explain not only the plight of the proletariat Black masses but the plight of both the Whites and Blacks in America. African American writers create their works as a tool to fight against the existing socio-political situations in America. They attempt to show their reactions against the economic situation by suggesting various ways through which their actions can effect change. This explains why the hero in Ralph Ellison's Invisible Man(1942) is happy to have discovered his invisibility. As a Black man, the white ghosts haunt him around, but as he discovers that he is invisible, he could see the realities of life. The hero is fighting a war without allowing his enemies to know that war is in progress. One night the hero accidentally accosts a blonde who sees him "because of the darkness" (IM,124). The blonde calls him an insulting name and he demand for an apology. The White man refuses but continues using more insulting words. The blonde is "mugged" (IM,124) to death by the invisible man who exerts his invisibility in other areas to buttress his heroic deeds. The discovery of his invisibility gives him an advantage over others.

African American writers use the narrative heroism in different forms and approaches to portray violence, in explaining the state of events of the African Americans which constantly lead to conflicts, violence and breakdown of peace and order. They create heroes who are independent and resourceful. For example, Baldwin's heroes exercise deeds that are a reflection of his autobiographical experiences. Wright's heroes are radical, forward and dangerously violent while Baldwin's heroes are dynamic, considerate, but they escape events at all times. The heroes in Native Son (1942) and The Man Who Killed a Shadow (1964) are notable marks. African American writers use their literary works to explain the forces in the American society in order to guide the readers to understand the situations Blacks suffer. This confirms the belief of Kafalenos that "narratives guide readers to discern a particular configuration in relation to which to interpret given events. Readers are led to include in a configuration certain revealed events and not others, primarily, by the relation between a suzette and its fibula - a relation that is illuminated by gaps" (48).

\section{American Dream in Literary Discourse}

The American dream is presented to the African American as realistic but they were denied equal rights. The Blacks were discriminated against in all spheres of human contemplation. They were only used as cheap labourers and were not placed in relevant economic position in the political structure of America. The four essential freedoms as pronounced by Roosevelt D. Franklin were illusionary to the African Americans. The Whites in America intimidated the African Americans, they were also exploited and used for cheap labour in the White plantations and their wives sexually assaulted. Racial structures were put in place to check the movement of the African Americans. Despite the proclamation of the four essential freedoms, and the existence of racial structures that denied rights to the Blacks, a clear aberration of the principles of the four essential freedoms of Franklin D. Roosevelt, many Blacks made their way through to prominence in America.

DuBois (1868-1963) was among the African Americans who made great impacts among the Whites. He became a clear model and source of inspiration and courage to many African Americans. Though he died in Accra Ghana in 1963, as a citizen, after giving up on America, he inspired many African Americans. He was born in Great Barrington, Massachusetts, in America in 1868. He was an ardent scholar who started writing way back in his high school days. He enrolled at Fisk University in Nashville in about 1883. Here he discovered himself as a Black and made a lifelong commitment to his people and declares " A New loyalty and allegiance replaced my Americanism: henceforward I was a Negro"(Comprehensive Black Writers of America Anthology,363). Du Bois carved a niche in the udder of 
greatness despite the racial structures put to clog the progress and independence of the Black Americans. Another great Black America who left strong mark in the history of Black Americans is Booker T. Washington (1858-1915). Washington rose from the powerlessness and ignorance of slavery to the position of unexampled "power and prestige"(Comprehensive Black Writers of America Anthology,1972:410). He in a way played roles favouring the Whites. He was recognized by the white administrators as the sole voice that can give sway and vent to the African soul. According to Brisbane in "The Black Vanguard"(1900-1960) there is evidence in support of Washington`s strong political influence and his control over Black public opinion through "The New York Age" and "The Washington Bee" (1954-1970),two Black news papers in which the "Tuskegee machine" held a controlling interest. According to him, the "Tuskegee monitored every racial movement from William Monrose Trotter`s plan for racial activism to the plans for the annual Niagara conferences sponsored by Du Bois and his associates (CBW, 1972:410). Washington is the founder of the Tuskegee school (1881) which is the school that the African Americans see as a hope for their rise and equality with the Whites. But they become disillusioned on entry into the school for academic pursuit. The African Americans see the school as they see the founder Booker T. Washington as "the empty eyes" of the founder. The school is seen as a structure to emasculate the Blacks through a more efficient prop. In this regard the Four Freedom is unrealistic and not beneficial to the African Americans. Many other Africans Americans rose to fame. The likes of Marcus Garvey and George Washington Williams, the author of History of the Negro in America 1619 to 1880", made impressive impacts for the cause of the African Americans in America. Robert Brown Elliott on his speech on the "Civil Rights Bill" delivered in the United States Congress in January 6, 1874 which dwelled on the camouflage of the Four Freedom and the introduction of racial discrimination, oppression, subjugation, and disenfranchisement did not bar the African Americans from pushing forward and pursuing their goals. It was a matter of "alluta continua" for the African Americans in America.

The American Dream is presented as illusion of vision, as something that cannot be realized and is unachievable. The Great Gatsby by Scott Fitzgerald is a typical commentary and criticism of the phrase "American dream". Published in 1925, the work embodies a criticism of American experience particularly that which touches the political and historic attitude of life of the American society and the American citizens. The theme of The Great Gatsby is the withering of the American dream. According to Marius Bewley,(1954) this phrase "essentially represents the romantic enlargement of the possibilities of live on levels at which the material and the spiritual have become inextricably confused" (2). This has inevitably led to the problems that has always confronted American artist dealing with American experience -racial discrimination, oppressive policies against the African Americans and Coloured in America, job placement discrepancies among other subjugating oppressive tendencies existing in American. This tendency hinges greatly on the American vision of life at which the reality ends and the illusion begins. Historically, the American dream is anti-Calvinistic and believes in the goodness of nature and man. The Great Gatsby explores the American dream as it exists in a corrupt period, and it is an attempt to determine that hidden boundary that divides the reality from illusion. The illusion is more visible and realistic than the reality and it is embodied in the minor characters typified in Tom and Daisy who threaten to invade the whole of the pictures as presented by the writer. Conversely, the reality is embodied in the character of Gatsby and is opposed to the hard, tangible illusions. The reality is a thing of the mind, of the spirit, a promise rather than the possession or vision, a faith in the half-glimpsed but hardly understood possibilities of life. In Gatsby, Scott presents an America that is undefined, in-articulate and frustrated. The Great Gatsby is the acting out of the tragedy of the American vision of the Four Freedom. Gatsby, the protagonist represents the world of the ostentatious newly rich, who remains a romantic idealist. The American Four Freedom is presented to be real such that the Negro American whole-heartedly embraced it. For them it would guarantee freedom and blending with the white Americans. In The Great Gatsby, Gatsby is the archetypal American character, he is self made, a man who invents or re-invents himself. He believes in the American Dream. He believes that in America one can become anything. The American Dream is like an invention of reality. This is the way the African Americans conceived it until they gradually began to discover themselves and to see their hope and aspirations as illusionary.

America as a nation of mixed race and coloures is bridled with freedom, painful memories among the Negroes. The Negroes were denied of culture and humanity in the face of racial discrimination, this situation is in total aberration of the jingles of Roosevelt Franklin. The African Americans are denied meaningful education and essential positions in government. They are exposed to menial jobs, human degradation in all spheres of human endeavour. It is alarming and shocking that in the midst of the Four Freedom the Negroes live in fear of the Jim Crow laws and the brutalities of the Ku Klux Klan racist hammer. Violence is meted against the Negroes without justification and justice. The work of Richard Wright, Native Son (1941) epitomizes the fear of the average Negro family living in the 
midst of the white American. It is most painful and horrifying to find in common existence the degree of violence as stack realities against the backdrop of the pronouncement of the Four Freedoms.

In total aberration of the Four Freedom slogan of the American society are memories of pain and images which trail the Negro like a ghost in his shadow. According to Eko in her $28^{\text {th }}$ Inaurgural speech at the University of Calabar "the racism that hung over the lives of the Blacks accumulated into storm that burst into self hatred and bitterness as witnessed in Richard Wright`s Native Son and Black Boy" (17). Other painful memories are recorded in many other Africa - America writers. Heavier than the robust presentation of the Black experience in America by Wright is prayer of Jupiter Hammon "An Evening Thought: Salvation by Christ with penitential cries" for salvation from Christ, the only son of God. It is remarkable here that the same white who preaches salvation through sanctity of mind, equality of human race is the person involved in discriminatory tendencies against their Black neighbours in America. He states; "Salvation comes by Christ alone the only son of God. Redemption now to everyone that loves his holy word".(46) This is a lamentation that touches the heart as he continues; "Lord unto whom now shall we go, or seek a safe abode?.. salvation be thy leading staff to set the sinners free..."(47). In view of the illusion and fantasy in the posture of the American Dream as contained in Roosevelt's "Four Freedom" speech, many Black writers have not failed and did not fail to express their disappointment. Much remarkable is a "letter to Thomas Jefferson" Secretary of State by Benjamin Banneker in 1791 in which he addresses the issue of equality of all people irrespective of race and colour, the subjugating nature of the Black with trails of history of horrors and sorrows he also exposes the ingenuity of the black race in invention and articulation, he writes:

...And now sir all through my sympathy and affection for my brethren hath caused my enlargement thus far, I ardently hope that your candour and generosity will plead with you in my behalf when I make know to you that it was not originally my design but having taking up my pen in order to direct to you direct to you as a present a copy of an almanac, which I have calculated for the succeeding year I was unexpectedly and unavoidably led hitherto, (Black American writers, (52).

The facts contained in this letter are packed with emotion. It proves that the African Americans are unjustly subjugated as they have the memory mentality and ability to invent like other people from other races and much more that one universal father gave being to us all. This same type of expression found value and rendition in the folk literature such as tales, and prison songs. In "The talking mule" the narrator expresses his disgust and feelings thus:

Ole feller one time had uh mule.

His name was Bill.

Evah mawnin

Ole man go to ketch him

He say,

Come round Bill.

(Black Writers(457).

This expresses tacitly the approaches and regard of the Whites on the African Americans who are regarded as house pets to be used as they please. Also such prison songs as "No Mo cane on dis Brazis" speaks volume of the resistance put forward by Blacks against the onslaught of the Whites, the song states:

It ain't no mo cane on this brazis,

Dey don grine it all in molazzi

Well, de Cap'n standing and looking and crying

Well, it gittin col, my rows behine

Cap'n doncha do me like you did poshine ya did po shine,

You drive dat bully till he nen stone-blind

Cap'n, Cap'n you mus be blind

Keep on hollin an I almost flyin

(Black Writers 457). 
The horrors are found everywhere among the Blacks. Women are abducted and adopted leaving behind husband and children. This is done lawlessly, and with some degrees of freedom without element of hesitation. This is established in "Shorty George"

Well- a Shorty George, he ain no fren o min

Well-a Shorty George he ain no fren o min

Taken all de wimmins and leave de mens behind

$\mathrm{O}$ when I get back to Dallas, gonna walk an tell

$\mathrm{O}$ when I get back to Dallas gonna walk an tell

My mama died, Lord, when Ize a lad my mama died lord, when ize a lad

My mama died, Lord, when Ize a lad

Since then I been nuthin but bad ...(460)

African Americans showed agonizing situations in their life as slaves living in bondage with the White Americans, where oppression has no bounds. In "Pity a poor boy" this situation of the Blacks is evident with a gapping horror and it is established thus:

Pity a poor boy? Pity poor boy?

You ain' going to pity me down. Pity a poor boy? Pity poor boy?

Oh; Pity a poor boy? Pity poor boy?

I am water logged, I am fire bound,

I am climbin up a mountain on a slippery ground

My head`s under water

But I ain`t going drown ...(461).

These poems show the dimensions of aberration suffered by the slaves and ex-slaves in America and the reactions and resistance of the Blacks. In the event of such assault Black folks in their suffering speak of freedom. They have hope and express hope that they will not remain what they are in American politics and society. In "We'll Soon Be Free" their feelings and hopes of freedom when they die and are no longer alive to experience and witness the suffering they encounter are expressed thus:

$$
\begin{aligned}
& \text { We'll soon be free } \\
& \text { We'll soon be free } \\
& \text { We'll soon be free } \\
& \text { When the Lord will call as home } \\
& \text {...it won't be long } \\
& \text { (Black Writers, 3,2,) }
\end{aligned}
$$

Franz Fanon states that "until a man discovers who he is, he cannot recover what he has lost" (56). Claud Mckay in his protest poetry states emphatically;

$$
\text { If we must die, it should not be like hogs }
$$$$
\text { Hunted and penned in an in glorious spot }
$$

(BAW,493).

He also exhibits his love for America when he states in "America" that:

Although she feeds me bread of bitterness

And sinks into my throat her tiger's tooth

Stealing my breath of life, I will confess

I love this cultured hell that uses my youth (496).

He continues his show of love for American in his "From Home to Harlem" when we shows his enduring and endearing love for Harlem. He states in few lines that: 
Harlem' Harlem'” through Jake. "where else

Could I have this life but Harlem?

Good old Harlem! Chocolate Harlem! Sweet

Harlem!...(499).

Mckay in the poem "Pour Encomiums on Harlem His Beautiful Home", he display a memorial, a recollection of love for his home despite the discrepancies that exist there being quite hopeful of change. He also laments the hypocrisy in Christian religion, lamenting the fervent approach to God in his "Poor St Isaac's Church, Petrograd".

In the same manner, Countee Cullen's works are full of lamentation, regrets, and expression of confidence. In Threnody for a Brown Girl, he laments the violence death of a Black girl. The same emotional expression trail his work in "The loss of love" where he laments the loss of a dear one. In "Nothing Endures", he bestows confidence and courage by informing that in no distant time, things shall change for better. He states;

Nothing endures, not even

Love. . . nirvana gapes. For all things given; Nothing

Escapes, love not even (537).

The poetries of Harlem Renaissance as shown by Claude Mckay, Countee Cullen, Allain Locke among others capture the core achievements of the writers of this period -1920s, of Black American writers. These writers have unrelentingly expressed the experiences of the African Americans in America, they have been very vocal of the history and travails of the Negroes in American. In her novel Beloved, Toni Morrison recounts again the bitter experiences of the American slavery by the account of a woman who kills her daughter because of the love she had for her rather than allow her to be snatched by the slave catchers and sent back into slavery. In the novel Beloved, Morrison expresses the mysteries of mother-daughter relationship just in the same vein as looking at the mysteries of ghost that returns home. The return of the ghost is remarkable as it signifies in a way the impact of evil and echoes consciousness for a better life - change of attitude, temperament, and dispositions to others around.

\section{Possibilities of the American Dream}

The American history have been a chain of horrors, an odyssey of the stigma of slavery, humiliation and violence, issues which have affected the lives of African Americans, it is worthy to note that the conquest of American land by the Europeans was accompanied by tremulous amount of violence, massive destruction pre existing civilization, also the intense competition to Europeans powers resulted in much plunder and exploitation which bred slavery, helped to execute the exploration of American brought about a process of cultural interactions which are the product of slavery. According to Yettes the Blacks were quite useful in the economic development of American but are described derogatorily as "human scrap heaps" (17) they were discriminated against in all ramifications. They were oppressed and denied many rights in America. They thus lived in fear, emotional trauma and desperation. This condition is echoed by many Black writers to portray the expressions of the Negroes in America.

Richard Wright in his Black Boy, (1942) and Native Son (1941) portrays the experiences of the Black soul to fit into the American society. In Native Son, Bigger Thomas in fear picks a job with the Dalton's family, and on same day he loses it by killing his employers' daughter, Mary Dalton. Native Son is a book full of ironies which expose the discrepancies that exist between the Black and the White population in America. The possibilities expressed in the Bigger Thomas episode is the fact that even though the Blacks live in fear and oppression, they still find space to themselves and live above these inhuman treatments. Criminal tendencies are used as a means of expression of disgust. Wright in these novels, in his language and characters shows where the American society has deviated from the Four Freedoms statement of Roosevelt Franklin. In Native Son, it is obvious that Black actions on a White fellow are criminal, even when initiated by the White fellow. A Black who comes in contact with a White is a criminal and he earns a penalty for this. America, a land of cultural pluralism and being woven from the various African nations, through slavery, is a land where the Africans relied upon and hoped for as a means of survival.

Many Africans, most of them freed men accompanied the Spanish in their expedition in America. Men like Juan Garrido; Juan Cirtes; Nuflo de Olano and Juan Valiente, played crucial roles in the success of the of the expeditions often credited to the Spanish. The Africans are better known for their economic contributions in the development of America and their continuous struggles to live above oppression and subjugations in the face of the draconian policies and laws that tend to hinder their progress. African labour was essential for the success of gold, silver and diamond mines for present day Mexico, Hinduras, Columbia, Venuzuela, Peru, Chile, Bolivia and Brazil, all Africans have distinguished themselves in agriculture in various American states. The involvements of Africans in 
the economic industry in America have made it possible for Europeans to colonize America and the Carribeans. The issues raised above are abundantly treated by Martin R. Delany (1812-1885) in his various dissertations. Delany in "The Condition, Elevation, and Destiny of the coloured People of the United States, Politically Considered" expresses his vision of foresight in a tone which is secular and modern he encourages Black, reaction to states of oppression and subjugation. Ralph Ellison in Invisible Man (1952), explores the possibilities in the American states through the hibernation of the Invisible Man, the protagonist of the novel. The Invisible Man goes into hibernation, and abstraction which become disposed of with levity. This action enables him to re-examine himself and regain consciousness with himself. This action motivates his effort in order to survive and excel the chaos in the world, his world Louis Mitchell in "Invisibility" - Permanent or Resurrective"?, remarks on this when he says that the narrator's disappearance is to bring "meaning out of chaos, possibility out of meaningless anarchy" (383). The hibernation of the protagonist is his strength and courage to discover his true identity, it is the assertion of his humanity as a non -negotiable reality because he is conscious of his worth and individuality. This dawns on him from the consciousness that in spite of White oppression, his humanity is independent of racist attitudes, hence refuses to be "yes man", not to dance to the whims of anybody who calls himself his 'boss' (emphasis mine).

Again the possibilities of the American Dream are explored and expressed in Black culture. Being natives of various African descents, they brought together their different cultural values to the useful coloration of the American nation with rich cultural value. According to Uya O. Edet (1987), “... African slave in the New World created a universe which the African cultural impulse was unmistakable"'(205). The African- American despite their condition of entry and stay in America, under violence, humiliation, and threats are able to survive, grow, and transmit their African cultures to their descendants. The Blacks started showing elements of resilience of hope and spirit in the struggles for freedom from oppression and exploitation in various ways and forms. The 'work songs' of Blacks were early protest measures for the Blacks. Through these songs they expressed their disgusts and indignations to the way they were over used in the plantations. According to Bateye "The work songs were timid attempts of the Blacks to voice their frustration of bondage and desire for freedom. He explains that the theme of the 'Work Songs' and the 'Spirituals' were associated with the struggles of the Blacks to attain freedom"(178). The Negro Spirituals is significant because while they obviously were sung as hymns in praise to God, they were used to sound their call for freedom as they expressed their misery and suffering.

Phillis Wheatley and Olaudah Equiano were the first and earliest voices of Black literature in English in the $18^{\text {th }}$ century. Phillis Wheatley has good standing in the literary circles of Black literature. However this position contrasts immensely with those of other embittered Black writers in Bolton's Ghetto. She did not direct her works to the plight of the Blacks. Prominent in her poems and those of Jupiter Hammon's are issue of religious devotedness. They do not see any evil in the slavery of the Blacks. They see slavery as freedom from 'heathenism'. The Blacks anchored their desire for freedom on spiritual Heaven. Glaring in the work of Olaudah Equiano's The Interesting Narrative of the Life of Olaudah Equiano, or Gustavus Vassa, the African, written by Himself(1989) is the spirit of self -determination and defiance. The work is the first hand testimony against slavery and places emphasis on the atrocities of slavery. He pleads for its total eradication. Equiano uses his African origin to establish his credibility as a critic of European rapacity. His memories of his African origin are almost un reservedly positive. Freedom, other than the consolation of religion comes as the top drive of his life in slavery. In his autobiography, he narrates negatively the savagery of European slavery, the atrocity that was the "Middle Passage" thus:

Does not slavery itself depress the mind, and extinguish all its fire and every noble sentiment? But, above all, what advantages do not a refined people possess over those who are rude and uncultivated. Let the polished and haughty Europeans recollect that his ancestors were once, like Africans, uncivilized, and even barbarous. Did nature make them inferior to their sons? And should they too have been made slaves? Every rational mind answers, No.( Norton Anthology,150-151)

Also Moses Horton (1797-1883) who was both a slave and a poet expressed his feelings about enslavement. Concerned with romantic love, religion and death, in three of Horton's poems in Hope of Light shed light on his feelings about slavery. He opposes slavery openly. His poem, "Division of an Estate" is his subtle expression of rhetoric of protest and it pathetic rendition of the slave's plight at the moment of anxiety. His poems on slavery attack the injustices, rather than simply complain of the constraints of slavery and racism. Also Frederick Douglass (1818-1895) who rose through the ranks of the anti-slavery movement in the 1840s and 1850s to become Black America's most electrifying speaker and commanding writer, and a premier African-American leader and spokesman for his people during the latter half $\mathrm{f}$ the $19^{\text {th }}$ century, he dedicated his leadership to the ideal of building a racially integrated America in which skin colour would stop to determine an individual's social value and economic strength. 
He also directed his literary strength mainly to inspire among the Blacks the belief that colour need not be a permanent bar to their achievement of the American Dream, while reminding Whites of their responsibilities as Americans to give support to free and equal access to that dream for Americans in all races. In his Narrative of the Life of Frederick Douglass, An American Slave, Written by Himself, Douglass narrates the ordeals of slavery. James M. Whitefield in an anthology of poems entitled America and other Poems narrates the hypocrisies of America and the lies that underscored slavery. He expresses his moral outburst and bitterness on slavery in the work thus:

America, it is to thee

Thou boasted land of liberty,

It is to thee I raise my song,

Thou land of blood, and crime, and wrong.

It is to thee, my native land,

From whence has issue many a band

To tear the black man from his soul,

And force him here to delve and toil...

Stripped of those rights which Natures's God

Bequeath to all the human race,

Was it for this, that freedom's fires

Were kindled by your patriot sires?

Was it for this, they shed their blood

On hill and plain, on field and flood?

Almighty God! Tis this they call

The land of liberty and law

Part of its sons baser thrall

Than Babylonian ever knew

Are perpetrated in the name

Of God, the holy, just, and true;

(Northon Anthology,402-405).

The poem ends with a plea to God "of justice, virtue, love and truth", to "save" the blacks and "repay" America of it guilt, and "burst the bonds of every slave" (405).

They also show possibilities in their contributions to religious life and institution, music, song, dance, and folk lore. The 'Blues', 'Jazz' and 'Soul' of the United State of America, the 'Calypso' and 'Reggae' of the Caribbean, among others are epitomes of Black contributions to the life and existence of America. These music types are impressive commentaries on the human conditions of the Blacks in America. Jazz, for example, has been described by one of its greatest protagonists, Dizzy Gillespie, as "a creation in America not through any great education force, but from the souls of the people who were brought here through protest "( Uya, 2005:205). In the same token of emotion, the Negro Spirituals on their own capture the full range of human emotions, loneliness, challenge, commitment, patience tragedies, triumphs, failures, successes, trials, frustrations and faith, such folktales as "the talkin mules " explores the Black experience in America ,just as such blues as "goin down the road " and pity a poor boy" explore the horrors of oppression and subjugation meted against the Blacks. Alice Walker in Colour Purple, (1985), explores Black culture visible in America in her presentation of the tension attendant upon polygamous home and the achievement of the woman -under such marriage, she makes a high mark in her wisdom to link woman`s potential unto mutual success; (Eko, 39) Celia, the protagonist and Shug her husband`s lover, should have been arch enemies like cats and dogs relation but the reverse is the case. Through co-operation, mutual understanding and perseverance, they are able to make it economically, emotionally, in the face of male oppression. Moreover, Celia's, sister is married to an America missionary in Africa and their eventual return to America with an Africa daughter in-law complete the picture of strategic linkage of persons and places, (Eko, 40). This is the exhibition of Africa culture of 
hetero-sexual relationship and the ability of Africa women to survive the storm associated with it and still make economic progress and achieve dignity and fame.

Also Toni Morrison's Beloved (1985) is an exhibition of the Africa belief system -what the West regard as superstition-ogbanje, Soyinka and Clark "Abiku"( Donatus Nwogu, 1986). The novel is an exploration of mother-daughter relationship as well as the mysteries of ghosts who return home. Harlem Renaissance writers echo the beauty of Africaness. It is an epoch where writers like Claude Mckay, Langston Hughes, Zora Neale Hurston, Countee Cullen, among others, including Black American women writers, celebrate the Black self in the 1920s which also snowballed into the French Negritude Movement of the 1940s. This movement however, began in Paris and became planted in Africa by a French scholar and political figure, Leopold Sedar Senghor. The collective achievement of these Black writers and champions is the possibilities of the American Dream.

\section{Conclusion}

There have been a great longing and desire among the Blacks to be equal with their White counterparts in America. This desire culminated in numerous literary works by Black writers across the globe. Even practical action was enacted by Marcus Garvey`s religious approach to the Black question. In his “Back -to -African Movement, Marcus Garvey and his nationalist organization appealed to God for redemption. He says "God will answer our prayers against the wicked and unjust" (112) ; and strengthen us for the great work that must be done in His name and His Glory" (112). Martin Luther King Jnr's stringent approach to the Black cause also excited great consciousness among Blacks. His approach to the Black cause gave vent to the "Black Power Movement" which is witnessed even today. This also led to the emergence of the "Student's Non- Violence coordinating Committee (SNCC) in the 1960s. This movement aligns with the literary movement and echoes of the 1960s.The literary echoes heralded the 1961 McComb Missippi voter's registration action. Until 1964, it was a biracial organization. According to Charles V. Hamitton, " this organization influenced by Malcom X and Franz Fanon moved towards a new emphasis on Blackness"(136).

According to Lauri Lyons, the 2009 inauguration speech of President Barack Obama was not only a bold step forward for the United States, but also served as a point of reflection on the events that paved a long road to equality. As has been shown above, literary discourse of the early 1960's echoed turbulent struggles for justice and equality for America's citizens. It is on record that in 1963, over two hundred thousand (200,000) people mobilized for a march on Washington. The march was intended to demand equal job opportunities, but made history for Dr Martin Luther King Jnr's “I have a Dream's Speech” (1963). This declaration by Martin Luther King Jnr was more than a speech, it was a challenge for the American people to become larger than words. In the face of non-violent movement for equality, there was violence that was executed with the use of attack dogs, fire horses and murder. It was a violent resistance that divided the nation and shocked the world.

This and the march in June,1966, after the killing of James Meredith set the stage for the appearance of the "Black Power" slogan which has culminated in the realization of the dream for a Black President, the $44^{\text {th }}$ President of America, President Barack Husein Obama. Obama's ascendancy to the Presidency complements late Martin Luther King Jnr's "I have a Dream" speech delivered in 1963 in Washington. His victory, as well as his inaugural speech is a clarion call to everyone, all nations to join hands together and build the world, for his success is not his alone but the world's and his progress is the progress of the entire world, because:

This is the meaning of our liberty and our creed - why men and women and children of every race and every faith can join in celebrating across this magnificent mark and why a man whose father less than sixty years ago might not have been at a local restaurant can now stand before you to strike a most sacred oath (237).

The literary echoes against Black Violence seem to have yielded fruit in the election of an African American as the $44^{\text {th }}$ president of America. This has been the hope and aspiration of all African Americans for a voice in the scheme of affairs in America. Thus he - Obama - reminds every individual of their responsibilities to maintain and sustain the victory. He says "... With hope and virtue, let us brave once more the current and endure what storms may come"(239).

Actually Obama, an African American has ruled America for eight years, but the questions still remain that has " the American Dream" been realized?, has there been restoration of equality and recognition of other races that constitute the entire population of America? Has the victory of Obama solved the race palava and injustice existing in the American nation. It is remarkable to note that in emphasizing his victory, he stated further that 
Let it be said by our children's children that when we were tested refused to let this journey end, that we did not turn back nor did we falter, and its eyes fixed on the horizon and God's grace upon us, we carried forth that great gift of freedom and delivered it safely to future generation (239).

Lauri Lyons has remarked that the 2009 inauguration speech of President Hussein Barrack Obama was not "only a bold step forward for the United States, but also served as a point of reflection on the event that paved a long road to equality"(23). The reflection calls to question the conditions of the Blacks during Obama`s rule, the Black yearned for a Black messiah who came in the person of Barrack Obama. The Black must inevitable be satisfied and make tremendous progress and development in all ramifications. It is evident that there is high level of expectation on the Black-man who becomes the president of America the expectation of the Black population is that after mirage of terrorism, natural disasters, war, and economic depression, Obama will take care of everything and everyone. They also expect that he will get all this done in eight years according to Lauri Lyons "with all the positive media attention and the celebrity states, it seems one of the biggest challenge that face President Obama which is something that President George Bush never contemplated and experienced on seat as president. To many Blacks they believed that Obama`s election will end white guilt regarding slavery, Jim Crow and racism. President Obama in the unfolding history of America in the $21^{\text {st }}$ century has become something greater than himself. He has inevitably become the realization of a national dream.

\section{References}

AJawara, Nedu. (2009). The Rise of Obama: The First Black President of USA. THE $44^{\text {th }}$ President of America. Lagos: Rosh \& Manholder Mustapha.

Anifowose, Remi. (1989). Violence in Politics. Lagos:Malthouse Press.

Baldwin, James. (1955). Notes of a Native Son. Boston: Beacon.

Barksdale, Richard \& Kinnamon, Kenneth. (1972). Black Writers of America: A Comprehensive Anthology. New York: Macmmillan.

Bateye, Oluwalomologye O. (2003). Black American Music as Propaganda for Democracy and Human Rights. Eds. Shamsudeen O. et al Ethnicity, Citizenship and Democracy in the United States of America. Ibadan: Humanities Publishers, 175-185.

Bewley, Marius. (1954). The Sewanee Review, 62(2), 223-246.

Bishop, Donald M. (2005). The Four Freedom Revisited, eds Nkpanom C. Ejituwu (et al). The American Society Since the Four Freedoms. Benin: Mindex.

Bone, Robert. (1973). The Negro Novel in America. New Haven: Yale University Press.

Brisbane, Robert Hughes. (1970). The Black Vanguard: Origins of the Negro Social Revolution. 1900-1960(Judson,1970).

. (1974). Black Activism: Racial Revolution in the United States. 1954-1970(Judson, 1974).

Chapman, Abraham. (1982). The New Black Voices: An Anthology of Contemporary Afro-American Literature. New Jersey: Mentor Books.

Chinweizu,Onwuchekwa, Jemie; Madubuike, Ihechukwu. (1981). The West and the Rest of Us. Enugu. Fourth Dimension.

Crewe, Jonathan. (1999). Recalling Adamastor: Literature as Cultural Memory in South Africa, (eds) Crewe, V. Jonathan; Mieke Bal; and Leo Spitzer Acts of Memory: Cultural Recall in the Present. Hanover: NH University Press of New England.

Du, Bois William Edward Burghart. (1965). Souls of Black Folk in Three Negro Classics. New York: Avon.

Eko, Ebele O. Ewa. (2005). Struggles\& survival: Strategic Parallels in African and African-American Literary Experience: $28^{\text {th }}$ Innaugural Lecture, University of Calabar. Calabar: University Press.

Ellison, Ralph. (1972). Invisible Man. New York: Penguin.

Elliott, Brown Robert. (1874). Civil Rights Bill. A Speech delivered in a United States congress delivered in January $6,1874$.

Equiano, Olaudah. (1989). The Interesting Narrative of the Life of an African Written by Himself. London: Penguin. 
Fanon, Frantz. (1981). The Wreched of the Earth. New York: Penguin.

Fitzgerald, Scott. (1971). The Great Gatsby. New York. Penguin.

Garvey,Amy Jacques. (1970). Garvey and Garveyism. New York: Macmillan.

Gates, Hary and Neillie Y. (1997). Mackay. The Norton Anthology.African-American Literature. London: W.W. Norton and Company.

Horton, Moses. (1952). Three of Horton Poems: Hope of Light. London: Penguin.

Kafalenos, Emma. (1999). Not (Yet) Knowing: Epistemological Effects of Deferred and Suppressed Information in Narrative. (Ed) David Herman Narratology: Introduction to The Theory of Narrative. Columbus Ohio: Ohio State University Press.

Locke, Alain. (1977). The New Negro: Studies in American Negro Life. New York: Atheneum.

Lyons, Lauri. (2016). Barrack Obama and The American Dream. Nomads Magazine. M. huffpost.com/us/entr. 1 May 2011.Retrieved February, 2016.

Morrison, Toni. (1985). Beloved. New York: Alfred A. Knoff.

Nwogu, Donatus Ibe. (1986). West African Verse. An Anthology. Lagos: Longman.

Ogunyemi, Christopher Babatunde. (2006). Violence in African American Literature: A Comparative Analysis of Richard Wright's The Man Who Killed a Shadow and James Baldwin's The Fire Next Time. A Master's Program in Comparative Literature, c-level Thesis(15 ECTS Points) Hogskolan Dalarna, Sweden.

Shade, William G. \& Herrenkohi, Roy C. Seven on Black: Reflections on the Negro Experience in America. New York: J.B. Lippincott, n.d.

Toomer, Jane. (1983). Cane.New York: Plume.

Uya, Okon Edet. (1992). African Diaspora and the Black Experience in New World Slavery. Calabar: Clear Line.

Walker, Alice. (1985). Colour Purple. Sam Diego: Harcourt Brace.

Whitefield, James W. (1978). America and Other Poems. An Anthology. New York: penguin.

Wright, Richard. (1941). Native Son. New York: penguin.

. . . (1942). Black Boy. New York: penguin.

Yette, Samuel F. (1971). The Choice: The Issue of Black Survival in America. New York: G.P. Puttenham. 